\title{
Pre-Service Teachers' Conceptions of Specific Astronomy Concepts: A Longitudinal Investigation
}

\author{
Cumhur TÜRK (Corresponding Author) \\ Science Education Program, Faculty of Education, Ondokuz Mayıs University \\ Samsun, 55200, Turkey
}

Tel: 90-362-312-1919 ext. 5870 E-mail: cturk@omu.edu.tr

Nilay ŞENER

Science Education Program, Faculty of Education, Ondokuz Mayıs University

Samsun, 55200, Turkey

Tel: 90-362-312-1919 ext.5870 E-mail: nsener@omu.edu.tr

Hüseyin KALKAN

Science Education Program, Faculty of Education, Ondokuz Mayıs University

Samsun, 55200, Turkey

Tel: 90-362-312-1919 ext. 5867 E-mail: kalkanh@omu.edu.tr

Received: February 14, 2015 Accepted: March 9, 2015 Published: March 10, 2015

doi:10.5296/jsss.v2i2.7213 URL: http://dx.doi.org/10.5296/jsss.v2i2.7213

\begin{abstract}
The aim of this study is to determine the changes in the knowledge of pre-service Primary and Science teachers related to basic astronomy concepts occurring after four years of undergraduate study in education and the extent of and reasons for these changes. For this purpose, a "Basic Astronomy Test" involving 14 questions was administered to the pre-service Primary and Science teachers by education faculty members in the Black Sea Region of Turkey in the first (2009) and fourth (2013) years of their educations. In the data analysis, nonparametric Mann-Whitney $U$ tests and Wilcoxon signed ranks tests were used to
\end{abstract}


determine whether achievement levels of pre-service teachers in basic astronomy concepts are related to the teaching program, year and their gender. Data analysis revealed that although the knowledge of basic astronomy topics of the students attending a program for Primary and Science teaching were the same in the first year of education, a statistically significant difference was observed in the knowledge levels of pre-service Science teachers after a four-year undergraduate education. In addition, the study also revealed that pre-service teachers had some misconceptions about basic astronomy concepts in their first year of undergraduate education. We observed a decrease in a number of these misconceptions, but others remained unchanged at the end of a four-year of education. It is recommended to include an astronomy course in the curriculum of the Primary teaching program and to increase the hours of the astronomy courses in the curriculum of the Science teaching program.

Keywords: Astronomy concepts, Astronomy education, Pre-service teacher, Science education 


\section{Introduction}

Since the beginning of human history, human beings have always wondered about nature and the universe and tried to understand their basic functioning mechanisms to facilitate their lives. Astronomy, as the oldest science, has contributed greatly to the process of understanding oneself and the environment for thousands of years. Finally, by turning his telescope to the sky for the first time in human history, Galileo created a touchstone and accelerated the process of understanding nature and the universe. Currently, every concept of the space age that has entered into our daily lives makes having an astronomy-literate culture indispensable (Türk \& Kalkan, 2015).

Because astronomy is closely associated with other basic sciences (e.g., physics, chemistry, geology and mathematics), it plays a central role in the natural sciences. In addition to philosophy, astronomy, in general, contains important cultural content, such as the distant origins of humanity, our tiny place in space and time and cosmological issues. Achievements in the field of astronomy are directly associated with advanced technological methods, such as detector techniques for optical, electronic and other wavelengths, computer image processing and obtaining, storing and transferring very large amounts of data (Trumper, 2006a). Today, astronomy education takes place outside the classroom environment in various ways, such as through books, magazines, radio, TV, astronomy clubs, amateur-teen camps and the internet (Fraknoi, 1996).

Despite being the oldest science, studies related to astronomy education are relatively recent. With the launch of Sputnik in 1957, studies related to astronomy education gained momentum (Bishop, 2006). Developed countries restructured their educational programs so as not to fall behind in the space race and to bring the community into science concepts (Borghi, De Ambrosis, \& Massara, 1991; Department of Employment, Education and Training, 1989; National Research Council, 1996; Orpwood \& Souque, 1985; Secretary of State for Education and Science, 1983; Tomorrow 98, 1992). For this purpose, they made use of the visual richness of astronomy. This brought astronomy and astronomy education into the forefront.

Percy (2006) emphasized that astronomy has been a basic topic of education for centuries and explained the answer to "Why is astronomy still an important subject for the school curriculum?" in the following manner: astronomy is a discipline that has a great number of daily implementations; such as calendars, time, finding directions, seasonal-long-term climatic changes and a dynamic science that includes education in science, mathematics and technology. Astronomy in the classroom gives teachers the opportunity to use alternative experimental methods and provides many examples in terms of scientific modelling and simulations. An "Integrated approach" and "cross curricular connections" are concepts that have been growing in importance in developing curriculums; therefore, astronomy, which is an interdisciplinary field, becomes more important in education. In the light of all the aforementioned information, astronomy increases society's awareness of science and technology. This situation is the same in both developed and developing countries. 


\subsection{University Students' and Pre-Service Teachers' Knowledge of Astronomy Concepts}

Astronomy concepts are often abstract and require three-dimensional thinking (Yu, 2005). This makes it difficult to learn and comprehend the basic astronomy concepts properly. However, if learned correctly, the perception and comprehension abilities of the students would improve, thereby facilitating the learning of other abstract concepts in science education. This exposes the relationship between science education and astronomy. When studies conducted in the last thirty years are analyzed, it can be observed that the number of studies involving secondary school students (Baxter, 1989; Bisard, Aron, Francek, \& Nelson, 1994; Klein, 1982; Mant \& Summers, 1993; Sharp, 1996; Sneider \& Pulos, 1983; Trumper, 2001a, 2001b, 2006b; Trundle, Atwood, \& Christopher, 2002; Vosniadou, 1992; Vosniadou \& Brewer, 1992, 1994) is much greater than those involving college students (Kalkan \& Kiroglu, 2007; Bisard et al., 1994; Trumper, 2000, 2001c, 2003, 2006a; Zeilik, Schau, \& Mattern, 1998). Pasachof \& Percy (1990) tried to seek an answer to the questions "Should astronomy be taught as a separate course or as a part of other courses?" "Which subjects should be involved?" and "What age group and learning methods and techniques should be used in teaching astronomy concepts?" They reported that the majority of Primary teachers have inadequate knowledge related to astronomy and the concepts of astronomy are not taught with the instructional techniques appropriate to the mental development of the students, and therefore, students have a hard time understanding astronomy topics. Similarly, Bisard et al. (1994) conducted a study involving a total of 700 students from elementary schools through college to observe whether misconceptions about geography and science topics, as measured by a multiple-choice test, change with respect to level of education. One interesting finding of this study is that elementary school students and pre-service teachers have approximately the same level of success. They concluded that students' knowledge related to astronomy does not dramatically change after secondary education.

Analysis of the studies conducted with pre-service teachers revealed that college students have similar problems in understanding basic astronomy concepts. Zeilik et al. (1998) investigated the conceptions of science and non-science university majors of several physical and astronomical concepts. They found that, before entering an "Introduction to Astronomy" course at the university, only $10 \%$ of the students held the correct view of the Moon's rotation, $23 \%$ had the right conception of the Sun and approximately $30 \%$ knew the accepted scientific explanation of the phases of the Moon and the solar eclipse. Trumper (2001c) administered a 19-item test to 433 university students (156 in 1st year; 122 in 2nd year; 87 in 3rd year and 68 in 4th year), and students' misconceptions and the distribution of these misconceptions by grade level were examined. The findings reveal that pre-service high school teachers hold some misconceptions about several central topics in astronomy. Finally, Kalkan \& Kuroglu (2007) reported that pre-service Science and Social Studies teachers also have misconceptions about basic concepts in astronomy. They examined the changes in the correct answer rates of pre-service teachers during an academic year. They concluded that students have difficulties in explaining their position in the Earth in which they live and the concrete-abstract relationships between their location and other celestial bodies with the current basic scientific facts. 


\section{Macrothink}

From all these studies, there is a need to find out the changes in the knowledge and misconceptions (if any) about astronomy of pre-service Science and Primary teachers, who will be responsible for teaching astronomy subjects in primary and elementary schools in Turkey, during their university education. It was thought that it would be useful to perform a longitudinal study, which was found to be rare in literature. In addition, by comparing the changes in knowledge among pre-service Science and Primary teachers, it will be possible to demonstrate the problems in the astronomy teacher training policies of Turkey. For all these reasons, unlike other studies in the literature, this study was planned to explore the current situation of pre-service teachers, to study the problems in the long term (4 years), to observe changes, to find out the differences between teaching programs (Science and Primary teaching), to present the problems of astronomy teacher training policies and to find solutions for these problems.

Around the world, astronomy is taught as a separate, compulsory course in very few countries. In most countries, compulsory astronomy units are not even included in other courses. The typical situation is that basic astronomy topics (some descriptive concepts, such as night and day, seasons, the phases of the moon, planetary orbits, planets and stars) are taught to students age 10-14 within physics or geography courses (Percy, 2006). Similarly according to the Next Generation Science Standards (NGSS, 2013), students in Grades 5-8 should have a clear notion about day-night, phases of the moon, daily and seasonal changes in the length and direction of shadows, different positions of the sun, moon, stars at different times of the day, month, and year, eclipses of the sun and the moon, Earth's spin axis, Big Bang.

Before introducing astronomy standards in Turkey, it will be of use to introduce it to Science and Primary teachers. Science teachers teach basic information, skills and attitudes about the sciences of physics, chemistry, biology and astronomy in elementary schools (between grades 5 and 8). Primary teachers teach students basic mathematics, social sciences, natural sciences, art, sports, reading and writing in primary school (between grades 1 and 4). Astronomy is not taught as a separate, compulsory course in Turkey. In Primary schools, astronomy topics are included in Social Studies and Life Sciences courses (6-7 years) or Science courses (8-13 years) as separate units. In high schools, astronomy courses are taught as elective courses. However, students often fail to select this course due to a teacher shortage (Kalkan \& Kiroglu, 2007). In education faculty, astronomy courses are included only in undergraduate Science teaching programs (one term, 2 hours a week). According to the Board of Higher Education, which determines the course contents at universities in Turkey, the content of an astronomy course in the faculty of education is as follows;

- Definition, history and importance of astronomy

- Units used in astronomy

- Universal dimensions-distances

- Kepler's laws

- The structure of the solar system

- The structures and features of planets and satellites in the solar system

- Comets 
- The general structure of the universe

- The structure and features of galaxies

- The formation of stars (nebulae), supernova explosions, red giants, neutron stars, and white dwarfs

- The structure and features of black holes

Students in the Primary teaching program do not directly receive instruction related to basic astronomy topics in their four-year undergraduate programs; instead they are taught some astronomy topics in physics or field (pedagogy) courses, albeit indirectly.

Teaching basic astronomy concepts that are appropriate to the developmental levels of primary and elementary students is of great importance. In this case, because Primary and Science teachers are in charge of teaching basic astronomy topics, they should have sufficient knowledge to do so. For this purpose, this study aimed to determine the changes in the knowledge of pre-service Primary and Science teachers related to basic astronomy concepts occurring as a result of four years of undergraduate study in education. In addition, we also aimed to identify the misconceptions related to basic astronomy concepts of pre-service Primary and Science teachers who are supposed to teach astronomy courses to students 6-13 years old. In accordance with these purposes, we sought answers to the following questions:

a) What changes occur in pre-service Science and Primary teachers' knowledge and misconceptions related to basic astronomy concepts after a four-year undergraduate course of study in education?

b) Is there a significant difference between basic astronomy achievement test scores of pre-service Science and Primary teachers by gender?

c) What are the misconceptions of pre-service Science and Primary teachers related to basic astronomy concepts before and after faculty of education?

\section{Method and Material}

This descriptive study aims to determine the changes occurring in the basic astronomy achievement levels of first- and fourth-year students in Science and Primary teaching programs with respect to year level, teaching program and gender. Survey research designs are a type of quantitative research in which investigators administer a survey to a sample or to an entire population of people to describe the attitudes, opinions, behaviors, or characteristics of the population (Creswell, 2008).

In this study, the data were collected over time using panel studies, which is a longitudinal survey design. The panel study is a longitudinal survey design in which the researcher examines the same individuals at different times during the course of the survey (Fraenkel, Wallen \& Hyun, 2012). For this purpose, data were obtained from students attending a Science or Primary teaching program in their first and fourth years.

\subsection{Sample}

The study sample consists of first- and fourth-year students in a Science or Primary teaching 


\section{Macrothink}

Journal of Social Science Studies

ISSN 2329-9150

2015, Vol. 2, No. 2

program at a university in the Black Sea Region of Turkey. Simple random sampling, one of the random sampling methods, was used in the study.

Because this study was planned to be a longitudinal study, the Basic Astronomy Test ${ }^{*}$ (BAT) was administered to the same students as a pre-test and a post-test in 2009 when they started their education and in 2013 when they completed their university education. However, because some of the students changed programs after they started university or some of the students left to study at other universities, the numbers of participants who took the pre-test in their first year and the number of participants who took the post-test in their fourth year were different. Thus, while doing data analysis, only the answers of the pre-service teachers who took both tests were assessed. As a result, the number of samples is less than the number of students studying in the program of Science and Primary teaching. Table 1 presents the distribution of students in terms of their year of study, program and gender.

Table 1. The distribution of the research sample according to teaching level and gender

\begin{tabular}{llllll}
\hline \multirow{2}{*}{ Gender } & \multicolumn{2}{l}{ Pre-Service Science Teacher } & \multicolumn{2}{l}{ Pre-Service Primary Teacher } & Total \\
& $\mathbf{1}^{\text {st }}$ Year & $\mathbf{4}^{\text {th }}$ Year & $\mathbf{1}^{\text {st }}$ Year & $\mathbf{4}^{\text {th }}$ Year & \\
\hline Female & 70 & 70 & 65 & 65 & $\mathbf{1 3 5}$ \\
Male & 63 & 63 & 71 & 71 & $\mathbf{1 3 4}$ \\
Total & $\mathbf{1 3 3}$ & $\mathbf{1 3 3}$ & $\mathbf{1 3 6}$ & $\mathbf{1 3 6}$ & $\mathbf{2 6 9}$ \\
\hline
\end{tabular}

\subsection{Data Collection Instrument and Data Analysis}

A 14-item BAT was used to determine the students' knowledge related to basic astronomy concepts. Table 2 presents the subjects that are intended to be taught and misconceptions that are intended to be discovered by the test (Türk \& Kalkan, 2015).

\footnotetext{
${ }^{*}$ Test is provided in the Appendix.
} 


\section{Macrothink}

Table 2. Subjects and misconceptions targeted by the BAT

\begin{tabular}{|c|c|}
\hline Subjects targeted by the test & Misconceptions targeted by the test \\
\hline $\begin{array}{l}\text { - } \text { Day/night cycle } \\
\text { - } \text { Apparent motion of the Sun } \\
\text { - } \quad \text { Scale of the Solar System } \\
\text { - } \text { Phases of the Moon } \\
\text { - } \quad \text { Linear distance scales } \\
\text { - } \quad \text { Linear size scales } \\
\text { - } \quad \text { Seasonal changes } \\
\text { - } \quad \text { Solar eclipse } \\
\text { - } \quad \text { General structure of the Universe } \\
\text { - } \quad \text { Formation of the Universe } \\
\text { - } \quad \text { The center of the Universe } \\
\text { - } \quad \text { Artificial satellites } \\
\text { - } \quad \text { Constellations } \\
\text { - } \quad \text { Shape of the Earth }\end{array}$ & $\begin{array}{l}\text { - Day and night occur as a result of the } \\
\text { Earth moving around the Sun } \\
\text { - } \quad \text { Earth rotates from east to west. } \\
\text { - The rotation period of the Moon around } \\
\text { the Earth is one day / one year. } \\
\text { - The Moon will be a full moon during a } \\
\text { solar eclipse } \\
\text { - The Earth closer to the Sun in summer } \\
\text { than the in winter } \\
\text { - Seasonal changes result from the Earth's } \\
\text { getting closer to and moving away from the } \\
\text { Sun. } \\
\text { - The Sun is right on top ( } 90^{\circ} \text { ) somewhere } \\
\text { on Earth at noon time. } \\
\text { - } \quad \text { Earth is bigger than Jupiter. } \\
\text { - Jupiter is closer to Earth than the Sun is } \\
\text { - Polaris is the closest celestial body to the } \\
\text { Earth } \\
\text { - } \quad \text { Artificial satellites are very far from the } \\
\text { Earth and very close to the Moon. } \\
\text { - The Sun is at the center of the Universe. } \\
\text { - The universe was formed according to } \\
\text { the Theory of Creation. } \\
\text { - Constellations are not very far (they are } \\
\text { even closer than the Moon). } \\
\text { - The Earth is ellipse in shape. }\end{array}$ \\
\hline
\end{tabular}

Ten items of the BAT $(1,2,3,4,5,6,7,10,11$ and 13) were originally obtained from Sadler (1992), Zeilik et al. (1998), Lightman \& Sadler (1993), Trumper (2000) and Hufnagel (2002)'s studies and were translated into Turkish by language experts, and minor revisions were made to some of the questions in accordance with Turkey's geographical conditions. The remaining items $(8,9,12$ and 14) were developed by the researchers by considering the Science Education Programs in Turkey. The pilot study of the test was conducted with the students visiting the Astronomy Centre in university. The KR-20 reliability coefficient of the test was found to be 0.56 . This result is consistent with other studies of similar scale (Trumper, 2001a; 2001b, 2006a). 
To ensure the content validity of the test, the views of three faculty members who specialized in Science teaching and astronomy teaching program were obtained. When the views of these specialists were analyzed, the items that had $90-100 \%$ consistency were left in the test. The questions were analyzed, discussed and assessed individually so that they could especially uncover the targeted misconceptions. The test which initially had 19 questions was changed by taking the views of specialists into consideration during pilot studies. Five questions were taken out and the final version of the test had 14 questions. The questions were analyzed in terms of their relevance for the level of the intended population and item analyses were conducted. For item analysis, total achievement test scores of each of the 269 students were calculated and the scores were arranged from the highest to the lowest. The first $27 \%$ of the score ranking $(n=73)$ formed the upper group while the last $27 \%(n=73)$ of the score ranking formed the lower group. Item discrimination and difficulty were calculated. As a result of the item analysis, the average discrimination of the questions was 0.38 (good discrimination) and the average difficulty of the items was 0.50 (intermediate difficulty) (Burton, 2001). In terms of the structural validity of the scale, the significance of the difference between the scores from the upper group (27\%) and the lower group (27\%) was analyzed by using a Mann Whitney U test (Table 3). A significant difference was found between the scores of the two groups. This significant difference shows that the BAT could make a significant distinction between these two groups.

Table 3. Mann-Whitney U test results comparing the upper group and the lower group

\begin{tabular}{lllllll}
\hline Groups & $\mathbf{N}$ & $\begin{array}{l}\text { Mean } \\
\text { Rank }\end{array}$ & $\begin{array}{l}\text { Sum of } \\
\text { Ranks }\end{array}$ & $\mathbf{U}$ & $\mathbf{z}$ & $\mathbf{p}$ \\
\hline Upper Group & 73 & 110.00 & 8030.00 & 0.000 & -10.646 & $\mathbf{0 . 0 0 0 *}$ \\
Lower Group & 73 & 37.00 & 2701.00 & & & \\
\hline $\mathrm{p}<0.05$. & & & & & &
\end{tabular}

Statistical analysis was done using SPSS 19 software. Nonparametric Mann-Whitney U tests and Wilcoxon signed ranks tests were used to determine whether the achievement levels related to basic astronomy concepts of first- and fourth-year students from Science and Primary teaching programs change with respect to the teaching program, year level and gender. P values of 0.05 or smaller were considered statistically significant.

Students' responses to the BAT were expressed as percentages (\%) and misconceptions were identified from their responses.

\section{Findings and Discussion}

Mann-Whitney U and Wilcoxon signed ranks results of the first- and fourth-year students' responses to the BAT by program, year and gender and students' misconceptions are shown in tables. 


\section{Macrothink}

Journal of Social Science Studies

ISSN 2329-9150

2015, Vol. 2, No. 2

The achievement average and standard deviations by year for pre-service Science and Primary teachers' BAT scores are shown in Table 4.

Table 4. The descriptive statistics of pre-service Science and Primary teachers' BAT scores by year

\begin{tabular}{lllll}
\hline Program & Year & $\mathbf{N}$ & Mean & S \\
\hline Science Teacher & $\mathbf{1}^{\text {st }}$ & 133 & 5.7218 & 2.06469 \\
Training & $\mathbf{4}^{\text {th }}$ & 133 & 7.5940 & 2.23958 \\
Primary Teacher & $\mathbf{1}^{\text {st }}$ & 136 & 6.3162 & 2.21009 \\
Training & $\mathbf{4}^{\text {th }}$ & 136 & 6.4779 & 1.99246 \\
\hline
\end{tabular}

The percentages of the correct answers given to the questions are shown in Table 5. The average percentage of correct answers of students in Science teaching was $45.3 \%$ in the first year, and this ratio increased to $54.3 \%$ in the fourth year. On the other hand, these percentages were $45.1 \%$ and $46.3 \%$ in the first- and fourth-year students in Primary teaching, respectively. 
Table 5. Correct answer percentage for pre-service Science and Primary teachers by pre- and post-program status

\begin{tabular}{|c|c|c|c|c|}
\hline \multirow[b]{3}{*}{ Item } & \multicolumn{2}{|c|}{ Pre-Service Science Teacher } & \multicolumn{2}{|c|}{ Pre-Service Primary Teacher } \\
\hline & $\begin{array}{l}1^{\text {st }} \text { Year } \\
(\%)\end{array}$ & $\begin{array}{l}4^{\text {th }} \text { Year } \\
(\%)\end{array}$ & $\begin{array}{l}1^{\text {st }} \text { Year } \\
(\%)\end{array}$ & $\begin{array}{l}4^{\text {th }} \text { Year } \\
(\%)\end{array}$ \\
\hline & $\mathrm{N}=133$ & $\mathrm{~N}=133$ & $\mathrm{~N}=136$ & $\mathrm{~N}=136$ \\
\hline 1. Day-Night Cycle & 90.2 & 83.5 & 83.8 & 77.9 \\
\hline 2. Time zones & 66.9 & 60.2 & 61.8 & 52.9 \\
\hline 3. Moon's rotation & 48.1 & 63.9 & 50.0 & 64.0 \\
\hline 4. Solar eclipse & 32.3 & 42.9 & 30.1 & 27.2 \\
\hline 5. Seasons & 56.4 & 68.4 & 44.9 & 44.9 \\
\hline 6. Seasons & 8.3 & 12.8 & 11.8 & 12.5 \\
\hline 7. Sun overhead at noon & 20.3 & 60.9 & 46.3 & 46.3 \\
\hline 8. Dimensions & 59.4 & 66.9 & 53.7 & 52.9 \\
\hline 9. Distances & 29.3 & 24.8 & 29.4 & 33.1 \\
\hline 10. Distances & 23.3 & 30.1 & 16.2 & 15.4 \\
\hline 11. Centre of the Universe & 42.1 & 64.7 & 55.1 & 54.4 \\
\hline $\begin{array}{l}\text { 12. Formation of the } \\
\text { Universe }\end{array}$ & 62.4 & 78.9 & 61.8 & 66.2 \\
\hline 13. Relative distances & 34.6 & 29.3 & 22.1 & 22.8 \\
\hline 14. Shape of Earth & 60.9 & 72.2 & 64.7 & 77.2 \\
\hline Mean & 45.3 & 54.3 & 45,1 & 46.3 \\
\hline
\end{tabular}

To find out whether there was difference between the BAT scores of pre-service Science and Primary teachers at the beginning and at the end of their undergraduate programs, the distributions of the test scores from both programs were analyzed. Because the groups did not have normal distributions, the Wilcoxon signed ranks test, which is the nonparametric version of the dependent groups t-test, was used for analysis. Table 6 presents the test results. 
Table 6. Wilcoxon signed ranks test results of pre-service Science and Primary teachers' BAT scores by year

\begin{tabular}{|c|c|c|c|c|c|c|c|c|}
\hline Program & & & $\mathbf{N}$ & $\begin{array}{l}\text { Mean } \\
\text { Rank }\end{array}$ & $\begin{array}{l}\text { Sum of } \\
\text { Ranks }\end{array}$ & $\mathbf{z}$ & $\mathbf{p}$ & Cohen's d \\
\hline \multirow{4}{*}{$\begin{array}{l}\text { Science } \\
\text { Teacher } \\
\text { Training } \\
\left(1^{\text {st }}-4^{\text {th }}\right. \\
\text { year })\end{array}$} & \multirow[t]{4}{*}{$\begin{array}{l}\text { Post test- } \\
\text { Pre test }\end{array}$} & $\begin{array}{l}\text { Negative } \\
\text { Ranks }\end{array}$ & $19^{\mathrm{a}}$ & 48.53 & 922.00 & \multirow[t]{4}{*}{-6.692} & \multirow[t]{4}{*}{$.000 *$} & \multirow[t]{4}{*}{0.87} \\
\hline & & $\begin{array}{l}\text { Positive } \\
\text { Ranks }\end{array}$ & $95^{\mathrm{b}}$ & 59.29 & 5633.00 & & & \\
\hline & & Ties & $19^{\mathrm{c}}$ & & & & & \\
\hline & & Total & 133 & & & & & \\
\hline \multirow{4}{*}{$\begin{array}{l}\text { Primary } \\
\text { Teacher } \\
\text { Training } \\
\left(1^{\text {st }}-4^{\text {th }}\right. \\
\text { year })\end{array}$} & \multirow[t]{4}{*}{$\begin{array}{l}\text { Post test- } \\
\text { Pre test }\end{array}$} & $\begin{array}{l}\text { Negative } \\
\text { Ranks }\end{array}$ & $57^{\mathrm{a}}$ & 59.37 & 3384.00 & \multirow[t]{4}{*}{-0.342} & \multirow[t]{4}{*}{0.732} & \multirow[t]{4}{*}{-} \\
\hline & & $\begin{array}{l}\text { Positive } \\
\text { Ranks }\end{array}$ & $61^{\mathrm{b}}$ & 59.62 & 3637.00 & & & \\
\hline & & Ties & $18^{\mathrm{c}}$ & & & & & \\
\hline & & Total & 136 & & & & & \\
\hline
\end{tabular}

${ }^{*} \mathrm{p}<0.05$.
a. Post-test $<$ Pre-test.
b. Post-test $>$ Pre-test.
c. Post-test $=$ Pre-test.

According to the Wilcoxon signed ranks test results in Table 6, there is a significant difference between the astronomy achievement scores of pre-service Science teachers at the beginning of their undergraduate education (1st year) and at the end of their studies (4th year) $[\mathrm{z}=-6.692, \mathrm{p}<0.05]$. However, there is no significant difference between the astronomy achievement scores of pre-service Primary teachers at the beginning of their studies and at the end of their undergraduate education $[\mathrm{z}=-0.342$, $\mathrm{p}>0.05]$.

Effect size (Cohen's $d$ ) value that was calculated for Science teaching program was 0.87 . This results show that the effect size of study was high.

To determine whether there was difference between the BAT scores of pre-service Science and Primary teachers at the beginning and at the end of their undergraduate course of study in education based on their program, the test score distributions of both groups were checked. Mann-Whitney U test was used for analysis. Table 7 presents the test results. 
Table 7. Mann-Whitney U test results of pre-service Science and Primary teachers' BAT scores by program.

\begin{tabular}{llcccccc}
\hline Year & Program & $\mathbf{N}$ & $\begin{array}{l}\text { Mean } \\
\text { Rank }\end{array}$ & $\begin{array}{l}\text { Sum of } \\
\text { Ranks }\end{array}$ & $\mathbf{U}$ & $\mathbf{z}$ & $\mathbf{p}$ \\
\hline $\mathbf{1}^{\text {st }}$ & $\begin{array}{l}\text { Science Teacher } \\
\text { Training }\end{array}$ & 133 & 124.46 & 16553.00 & 7642.000 & -2.219 & 0.026 \\
& $\begin{array}{l}\text { Primary Teacher } \\
\text { Training }\end{array}$ & 136 & 145.31 & 19762.00 & & & \\
& $\begin{array}{l}\text { Science Teacher } \\
\text { Training }\end{array}$ & 133 & 153.91 & 20470.50 & 6528.500 & -3.980 & $\mathbf{0 . 0 0 0 *}$ \\
$\mathbf{4}^{\text {th }}$ & & & & & & \\
& $\begin{array}{l}\text { Primary Teacher } \\
\text { Training }\end{array}$ & 136 & 116.50 & 15844.50 & & & \\
\hline
\end{tabular}

$*_{p}<0.05$.

From Table 7 we see that no statistically significant difference was found between the BAT scores of first-year Science teaching and Primary teaching students [U=7642.000, $>>0.05]$. However, there was a significant difference between the basic astronomy achievement test results of fourth-year Science teaching and Primary teaching students [U=6528.500, $p<0.05]$. When the means of the ranks were examined, fourth-year Primary teaching students had lower ranking means than did those in Science teaching. This shows that Science teaching program fourth-year students have higher basic astronomy scores.

Table 8 shows the Mann-Whitney U test that explores the differences between BAT scores of 1 st and 4th year Science teaching and Primary teaching students by gender. 


\section{IIMacrothink}

Journal of Social Science Studies

ISSN 2329-9150

2015, Vol. 2, No. 2

Table 8. Mann-Whitney U test results of pre-service Science and Primary teachers'BAT scores by gender

\begin{tabular}{|c|c|c|c|c|c|c|c|c|}
\hline Program & Year & Gender & $\mathbf{N}$ & $\begin{array}{l}\text { Mean } \\
\text { Rank }\end{array}$ & $\begin{array}{l}\text { Sum of } \\
\text { Ranks }\end{array}$ & $\mathbf{U}$ & $\mathbf{z}$ & $\mathbf{p}$ \\
\hline \multirow{4}{*}{$\begin{array}{l}\text { Science } \\
\text { Teacher } \\
\text { Training }\end{array}$} & \multirow{2}{*}{$1^{\text {st }}$} & Female & 70 & 59.35 & 4154.50 & \multirow{2}{*}{1669.500} & \multirow{2}{*}{-2.441} & \multirow{2}{*}{$0.015^{*}$} \\
\hline & & Male & 63 & 75.50 & 4756.50 & & & \\
\hline & \multirow{2}{*}{$4^{\text {th }}$} & Female & 70 & 67.84 & 4749.00 & \multirow{2}{*}{2146.000} & \multirow{2}{*}{-0.269} & \multirow{2}{*}{0.788} \\
\hline & & Male & 63 & 66.06 & 4162.00 & & & \\
\hline \multirow{4}{*}{$\begin{array}{l}\text { Primary } \\
\text { Teacher } \\
\text { Training }\end{array}$} & \multirow{2}{*}{$1^{\mathrm{st}}$} & Female & 65 & 65.81 & 4277.50 & \multirow{2}{*}{2132.500} & \multirow{2}{*}{-0.770} & \multirow{2}{*}{0.441} \\
\hline & & Male & 71 & 70.96 & 5038.50 & & & \\
\hline & \multirow{2}{*}{$4^{\text {th }}$} & Female & 65 & 67.82 & 4408.50 & \multirow{2}{*}{2263.500} & \multirow{2}{*}{-0.194} & \multirow{2}{*}{0.846} \\
\hline & & Male & 71 & 69.12 & 4907.50 & & & \\
\hline
\end{tabular}

$*_{p}<0.05$.

When the results of Table 8 are examined, a significant difference is observed between the scores of first-year Science teaching students by gender, in favor of male students $[\mathrm{U}=1669.500, \mathrm{p}<0.05]$, while no significant difference was found between the scores of fourth-year Science teaching students in terms of gender [ $U=2146.000, p>0.05]$. When the results of Primary teaching students were analyzed, no significant difference was found between the scores of first-year [ $\mathrm{U}=2132.500, \mathrm{p}>0.05]$ or fourth-year students by gender $[\mathrm{U}=2263.500, \mathrm{p}>0.05]$.

Misconceptions related to basic astronomy concepts of first- and fourth-year students in the Science and Primary teaching programs and their prevalence rates are given in Table 9. 
Table 9. The percentages of the most widespread astronomy misconceptions of pre-service teachers by pre- and post-program status

\begin{tabular}{|c|c|c|c|c|c|}
\hline Concept & Misconception & $\begin{array}{l}\text { ST* } \\
1^{\text {st }} \text { Year } \\
(\%)\end{array}$ & $\begin{array}{l}\text { ST } \\
4^{\text {th }} \text { Year } \\
(\%)\end{array}$ & $\begin{array}{l}\text { PT** } \\
1^{\text {st }} \text { Year } \\
(\%)\end{array}$ & $\begin{array}{l}\text { PT } \\
4^{\text {th }} \text { Year } \\
(\%)\end{array}$ \\
\hline Day-Night cycle & $\begin{array}{l}\text { Earth moves around } \\
\text { the sun }\end{array}$ & 4.5 & 14.3 & 10.3 & 17.6 \\
\hline $\begin{array}{l}\text { Time zones (time } \\
\text { difference between } \\
\text { Samsun and Beijing) }\end{array}$ & 6 hours ago & 17.3 & 24.8 & 14.0 & 19.1 \\
\hline \multirow{2}{*}{$\begin{array}{l}\text { Moon's rotation } \\
\text { (around Earth) }\end{array}$} & One day & 22.6 & 15.0 & 18.4 & 22.8 \\
\hline & One year & 13.5 & 10.5 & 20.6 & 9.6 \\
\hline $\begin{array}{l}\text { Moon's phase in Solar } \\
\text { eclipse }\end{array}$ & Full moon phase & 54.9 & 46.6 & 41.2 & 53.7 \\
\hline Seasons & $\begin{array}{l}\text { Earth closer to sun in } \\
\text { summer }\end{array}$ & 39.1 & 23.3 & 28.7 & 36.8 \\
\hline $\begin{array}{l}\text { Seasons } \\
\text { (If the distance between } \\
\text { the Earth and sun } \\
\text { would remain the same } \\
\text { throughout the year) }\end{array}$ & $\begin{array}{l}\text { There would be no } \\
\text { seasons }\end{array}$ & 63.9 & 49.6 & 55.9 & 47.8 \\
\hline $\begin{array}{l}\text { Sun overhead at noon } \\
\text { (in Samsun city) }\end{array}$ & Everyday at noon & 54.1 & 15.0 & 26.5 & 27.2 \\
\hline Dimensions & $\begin{array}{l}\text { Earth bigger than } \\
\text { Jupiter }\end{array}$ & 23.3 & 12.0 & 11.8 & 23.5 \\
\hline \multirow[b]{2}{*}{ Distance from Earth } & $\begin{array}{l}\text { Jupiter closer than } \\
\text { sun }\end{array}$ & 18.8 & 33.1 & 24.3 & 25.0 \\
\hline & $\begin{array}{l}\text { Polaris closest } \\
\text { celestial body to the } \\
\text { Earth }\end{array}$ & 18.8 & 21.1 & 18.4 & 14.7 \\
\hline \multirow{2}{*}{$\begin{array}{l}\text { Distance (artificial } \\
\text { satellite) }\end{array}$} & $\begin{array}{l}\text { About half way to the } \\
\text { Moon }\end{array}$ & 35.3 & 29.3 & 39.7 & 32.4 \\
\hline & $\begin{array}{l}\text { Very close to the } \\
\text { Moon }\end{array}$ & 23.3 & 23.3 & 17.6 & 30.1 \\
\hline Center of the Universe & The Sun & 35.3 & 21.1 & 22.8 & 26.5 \\
\hline Formation of the & Creation theory & 22.6 & 9.8 & 19.9 & 11.8 \\
\hline
\end{tabular}




\section{Universe}

\begin{tabular}{|c|c|c|c|c|c|}
\hline $\begin{array}{l}\text { Relative distances } \\
\text { (constellations) }\end{array}$ & $\begin{array}{l}\text { Constellations closer } \\
\text { than Moon }\end{array}$ & 37.6 & 35.3 & 32.4 & 31.6 \\
\hline Shape of Earth & Ellipse & 34.6 & 19.5 & 17.6 & 14.0 \\
\hline
\end{tabular}

* Science Teacher

** Primary Teacher

\subsection{Question-by-Question Analysis}

In this part of the study, the changes in the percentages of correct answers and misconceptions of pre-service teachers for each question were presented and discussed. In addition, the findings were compared with other studies in literature that used similar tests.

Table 10 presents a comparison of the correct answers to the questions given by pre-service teachers and the results of the studies by Zeilik et al. (1998; 1999), Trumper (2000; 2001c) and Kalkan \& Kiroglu (2007) that used similar tests on university students. 
Table 10. A comparison of the percentages of correct answers given to researchers that used some of the questions in BAT

\begin{tabular}{|c|c|c|c|c|c|c|c|c|c|}
\hline & ST1 & ST4 & PT1 & PT4 & $\begin{array}{c}\text { Trumper } \\
\text { (2000) } \\
\text { (Israel) }\end{array}$ & $\begin{array}{c}\text { Trumper } \\
\text { (2001c) } \\
\text { (Israel) }\end{array}$ & $\begin{array}{c}\text { Zeilik } \\
\text { et al. } \\
\text { (1998) } \\
\text { (U.S.A) }\end{array}$ & $\begin{array}{c}\text { Zeilik } \\
\text { et al. } \\
\text { (1999) } \\
\text { (U.S.A) }\end{array}$ & $\begin{array}{c}\text { Author } \\
\text { (2007) } \\
\text { (Turkey) }\end{array}$ \\
\hline $\begin{array}{l}\text { Day-Night } \\
\text { Cycle }\end{array}$ & 90.2 & 83.5 & 83.8 & 77.9 & 62 & 52 & - & - & 92 \\
\hline $\begin{array}{l}\text { Time } \\
\text { zones }\end{array}$ & 66.9 & 60.2 & 61.8 & 52.9 & 49 & 39 & 48.5 & - & 53 \\
\hline $\begin{array}{l}\text { Moon's } \\
\text { rotation }\end{array}$ & 48.1 & 63.9 & 50.0 & 64.0 & 60.5 & 56 & 40 & 38 & 20.5 \\
\hline $\begin{array}{l}\text { Solar } \\
\text { eclipse }\end{array}$ & 32.3 & 42.9 & 30.1 & 27.2 & 22.4 & 19 & 55.5 & 55.5 & 34 \\
\hline Seasons & 56.4 & 68.4 & 44.9 & 44.9 & 50 & 53 & - & - & 68 \\
\hline $\begin{array}{l}\text { Sun } \\
\text { overhead } \\
\text { at noon }\end{array}$ & 20.3 & 60.9 & 46.3 & 46.3 & 32.9 & 26 & 43.5 & 44 & 34 \\
\hline Distances & 29.3 & 24.8 & 29.4 & 33.1 & 50 & 39 & - & 44.5 & 58.5 \\
\hline $\begin{array}{l}\text { Centre of } \\
\text { the } \\
\text { Universe }\end{array}$ & 42.1 & 64.7 & 55.1 & 54.4 & 73.7 & 55 & - & - & 76.5 \\
\hline $\begin{array}{l}\text { ST1. Science } \\
\text { ST4. Science } \\
\text { PT1. Primary } \\
\text { PT4. Primary }\end{array}$ & $\begin{array}{l}\text { Tea } \\
\text { Tea } \\
\text { Tea } \\
\text { Tea }\end{array}$ & $\begin{array}{l}\operatorname{er}\left(1^{\text {st }}\right. \\
\operatorname{er}\left(4^{\text {th }}\right. \\
\operatorname{er}\left(1^{s}\right. \\
\operatorname{er}\left(4^{\text {th }}\right.\end{array}$ & $\begin{array}{l}\text { Year). } \\
\text { Year). } \\
\text { Year). } \\
\text { Year). }\end{array}$ & & & & & & \\
\hline
\end{tabular}

When Table 10 was reviewed, it can be seen that Turkish pre-service teachers are better than Israeli students in subjects such as "day-night cycle, time zones, solar eclipse, sun overhead at noon" and they are better than students from the U.S.A. in subjects such as "time zones and Moon's rotation". However, it can also be seen that Israeli students are better than Turkish students in subjects such as "universal distances, center of the universe" and students from the U.S.A. are better than Turkish students in subjects such as "sun overhead at noon, universal distances, solar eclipse”. The results of another study by Kalkan \& Kiroglu (2007) that used similar questions are in parallel with our study in general except for the subjects of "moon's rotation, distances, center of the universe".

Question 1 (Day-night cycle): The first question in the scale is about the position of the planet that we live on (the Earth) in relation to the Sun and possible changes. Most of the students 
gave the correct answer. The correct answer rates of the students in Science teaching were $90.2 \%$ and $83.5 \%$ in the first and fourth years, respectively. These rates were $83.8 \%$ and $77.9 \%$ in the first and fourth year students in Primary teaching. The most common misconception among students is that "day and night occur as a result of Earth's revolution around the Sun". The rate of misconceptions in students from the Science and Primary teaching programs increased in the fourth year. Having a decrease in the rate of correct answers and an increase in the rate of misconceptions among students is noteworthy. This situation shows that about the reason of the occurring of day and night, which is observed by us every day, pre-service teachers tend to answer based on daily observations over the years. This is because our daily observations show us that the Sun rises, changes its location during the day and sets at night, that is, the Sun revolves around the Earth.

Question 2 (Time zones: time difference between Samsun and Beijing): The second question aims to assess the pre-service teachers' conception about the motion of the Earth in the Solar System and its relation to our daily lives. In addition, this question also assesses the students' knowledge about geographical locations and the rotation of the Earth around the Sun. When pre-service teachers' responses were analyzed, it was revealed that the number of correct answers in both group decreased (from $66.9 \%$ to $60.2 \%$ in Science teaching and from $61.8 \%$ to $52.9 \%$ in Primary teaching). Having a decrease in the correct answer rates of the students was attributed to the training that they received at the faculty of education. For this question, students thought that time in Beijing, which is $90^{\circ}$ to the east of Samsun, was earlier that in Samsun (while noon in Samsun, it is morning in Beijing). Misconceptions of students in both programs further increased in the fourth year of education. Students do not know exactly for sure which direction the Earth rotates around its own axis (From the west towards the east? From the east towards the west?).

Question 3 (Moon's rotation): The third question aims to determine the perceptions of students about the revolution period of the Moon around the Earth based on the relationship between the Earth and the Moon. The ratios of correct answers in both groups were similar (48.1\% and $63.9 \%$ in the first- and fourth-year students in Science teaching, respectively; $50 \%$ and $64 \%$ in the first- and fourth-year students in Primary teaching, respectively). However, there were misconceptions about the revolution period of the Moon around the Earth (one day or one year) in both groups. There are confusions about the views of the students on the Earth's rotation around its own axis, the Earth's revolving around the Sun and the time it takes for the Moon to rotate around the Earth. Pre-service teachers have misconceptions on the mechanical relation between the Earth and the Moon that is the closest celestial body to the Earth and the Earth's satellite, and the Sun which is the closest star to the Earth and the Earth's source of life.

Question 4 (Moon's phase in Solar eclipse): The fourth question deals with the abstract mechanical relationship between the sun, the Earth and moon's phases. Striking findings were obtained from the fourth question. In the first year, $32.3 \%$ and $42.9 \%$ of fourth-year students in Science teaching and $30.1 \%$ of first year and $27.2 \%$ of fourth year students in Primary teaching stated that the Moon will be in the "new moon phase" during a Solar eclipse. While the correct answer rate of pre-service Science teachers increased after a four-year 
undergraduate education, this ratio decreased in students from the Primary teaching program. Students' responses revealed that most of the students answered with the "full moon phase" option. The rate of misconceptions decreased in the fourth year among Science teaching (from 54.9\% to $46.6 \%$ ) students but increased among pre-service Primary teachers (from $41.2 \%$ to $53.7 \%$ ). This difference can be explained by the contents of the two different curricula; in other words, the topic of "phases of the Moon" is included in Science teaching but not in Primary teaching.

Question 5 (Seasons): The fifth and sixth questions in the scale are very important because they aimed to determine whether the concept of season, which is frequently involved in Turkish primary and elementary school curriculums, is learned on the levels of "understand" or "apply" by the students. The students were asked the question of seasons on the levels of "understand" (making comparisons and associations between events) and "apply" (implementing the existing knowledge to a new situation) question according to Bloom's cognitive process dimension that aims to assess how the information is transferred to another situation (Krathwohl, 2001). When the answers to the fifth question were analyzed, an increase was seen in the correct answers of Science teaching students $(56.4 \%$ in 1 st year and $68.4 \%$ in 4 th year) while no change was observed in the correct answers of Primary teaching students (44.9\% in the first and fourth years). About one third of the students stated that the reason why summers are warmer is because the "Earth is closer to the Sun in summer" and associated the differences in temperature with the concepts of proximity and distance. This misconception in pre-service teachers became permanent in the fourth year.

Question 6 (Seasons): The sixth question was prepared based on the option in the fifth question (The Earth is closer to the Sun in summer). In first-year students, $63.9 \%$ and in fourth-year students, $49.6 \%$ of students from the Science teaching program and $55.9 \%$ of first-year and $47.8 \%$ of fourth year-students from the Primary teaching program had the misconception that "the difference between the seasons would disappear and there would be a single season" if the distance between the Earth and the Sun remained the same. This thought supports the opinion that "the Earth is closer to the Sun in summer" in the fifth question. The correct answer rates for this question were $8.3 \%$ and $12.8 \%$ for the first- and fourth-year students in Science teaching and $11.8 \%$ and $12.5 \%$ for the first- and fourth-year students in Primary teaching, respectively. The correct answer rate for the fifth question, a level of understand question, was higher than that for the sixth question, a level of apply question.

Question 7 (Sun overhead at noon): The seventh question is about the relationship between the Earth's axial tilt and the Sun and its impact on our position on the Earth. The correct answer rates for this question were $20.3 \%$ and $60.9 \%$ for the first- and fourth-year students in Science teaching, respectively, showing a great increase. No change was observed in the answers of the students of Primary teaching (46.3\% in the first and fourth years). For this question, the most important misconception is that the Sun will be overhead at "everyday at noon" (in Samsun). Misconceptions of Science teaching students decreased at the end of their four-year undergraduate education (from $54.1 \%$ in 1 st year to $15 \%$ in 4 th year). For Primary teaching students, this misconception was ingrained and did not change significantly $(26.5 \%$ 
in the first year and $27.2 \%$ in the fourth year). Students having this misconception could not comprehend the relationship between their geographic position and the Sun overhead. Additionally, it was thought that students mistake the concepts of the highest position of the Sun in the sky and it being overhead.

Question 8 (Dimensions): This question aims to determine the students' conceptions of the size of celestial bodies in the Solar System. Students were asked to order the celestial bodies by size. The correct answer rates were $59.4 \%$ and $66.9 \%$ in the first and fourth year, respectively, for students in the Science teaching program. These rates were $53.7 \%$ and $52.9 \%$, respectively, for the students in the Primary teaching program. For this question, the most important misconception is that "the Earth is bigger than Jupiter." As seen in Table 9, misconceptions of students in Science teaching decreased in the fourth year but increased for the students in Primary teaching. The reason might be that the topic of "Solar System" is included in the Science teaching curriculum but not in the Primary teaching curriculum.

Question 9 (Distance from Earth): This question was designed to assess the perceptions of the "universal distance" concept. The students were asked to order the celestial bodies according to their distance from the Earth. However, only one-third of the students gave the correct answer to this question. Interestingly, the correct answer rates of the students in Science teaching decreased from $29.3 \%$ to $24.8 \%$ after a four-year education program, but this rate increased from $29.4 \%$ to $33.1 \%$ for the students in Primary teaching. Students had more than one misconception in this question. These are as follows: "Jupiter is closer to the Earth than the Sun is" and "Polaris is the closest celestial body to the Earth." When the pre-service teachers were in their last year, it was seen that the aforementioned misconceptions did not decrease; on the contrary, they became more rooted. There is no astronomy course in the curriculum of Primary teaching undergraduate program. However, there is astronomy course in the curriculum of Science teaching undergraduate program. The fact that the students of Science teaching program showed a decrease in the number of correct answers and an increase in the number of misconceptions although they learned the knowledge about "universal distance" in astronomy courses is a very important problem in terms of the quality of astronomy education in Turkey.

Question 10 (Distance (artificial satellite)): The tenth question in the scale aims to determine how closely the students follow space technology. The rate of correct answers of Science teaching students in this question was $23.3 \%$ in the first year and $30.1 \%$ in the fourth years. Not much change was seen in the rate of correct answers of Primary teaching students in this question $(16.2 \%$ in 1 st year and $15.4 \%$ in 4 th year). It was seen that the students of both programs gave the correct answer to this question in very low rates. Students had two misconceptions in this questions; the first one is that Turksat B artificial satellite is approximately at a point "about half way to the Moon." The second one is that location of the Turksat B artificial satellite is "very close to the Moon." The students' misconception percentages were higher than their percentages of correct answers. The students probably imagine that universal distance is very far away and when they implement this knowledge to space technology, they make mistakes. The fact that the students think that Turksat B is so far away from the Earth at the same time shows that they could not implement their knowledge 
on gravitation to this question. If they had used their knowledge about the approximate mass of the Earth and Turksat B artificial satellite and gravitational force, they could have figured that an artificial satellite cannot be very far from the orbit of the Earth.

Question 11 (Center of universe): The correct answer rates for this question increased from $42.1 \%$ to $64.7 \%$ in the last year for Science teaching students but decreased from $55.1 \%$ to $54.4 \%$ for the Primary teaching students. This result showed that Copernicus's perception of the universe in the middle ages, namely, "the Sun is the center of universe" is still dominant among students. This misconception decreased for the students in Science teaching in the fourth year but increased in students in Primary teaching.

Question 12 (Formation of universe): In the twelfth question dealing with "how the universe was formed," the rates of correct responses (Big Bang) in both groups were high $(62.4 \%$ and $78.9 \%$ in Science teaching and $61.8 \%$ and $66.2 \%$ in Primary teaching). An alternative thought for this question was "Creation theory which asserts that everything was created out of nothing over time." However, a reduction was observed in these thoughts in both groups of students. Although the scientific theory about how the universe was formed is Big-Bang, it is thought that the students who support the Creation theory prefer their experiences that they get from their cultures and beliefs.

Question 13 (Relative distances [constellations]): Analysis of the thirteenth question, which aims to measure knowledge about the changes in the appearance of constellations by the position of the Earth, showed that students have no clear idea on this issue. The correct answer rates were $34.6 \%$ and $29.3 \%$ in the first and fourth year, respectively, in Science teaching and $22.1 \%$ and $22.8 \%$ in the first and fourth year, respectively, in Primary teaching. It was seen that the students had very low rates of correct answers to this question. The students were found to have more misconception than correct answers. This misconception was "constellations are closer than the Moon". 37.6\% of the first year and 35.3\% of the fourth year Science teaching students had this misconception while $32.4 \%$ of the first year and $31.6 \%$ of the fourth year Primary teaching students had this misconception. It can be seen that the education pre-service teachers had during their four years leads them to the misconception rather than the correct answer. When the content of the astronomy course in Science teaching undergraduate is analyzed, it can be seen that there are no subjects on constellations. This situation can be seen in the results.

Question 14 (Shape of Earth): This question aims to expose students' thoughts about the shape of the Earth. $60.9 \%$ of the first year and $72.2 \%$ of the fourth year Science teaching students answered the shape of the Earth correctly while $64.7 \%$ of the first year and $77.2 \%$ of the fourth year Primary teaching students answered the question correctly. Students' response to this question revealed that students mistake for the shape of the Earth with an "Ellipse" which is the shape of the Earth's orbit around the Sun. This mistake was still observed in the fourth year of both Science teaching and Primary teaching students.

\section{Conclusions}

Astronomy involves concepts that require high-level observation and thinking skills. 
However, this study put forth that pre-service teachers have difficulties even in basic concepts in astronomy. Pre-service teachers' knowledge about astronomy concepts in the first and fourth years of an undergraduate education program did not change and a decline in the rate of correct answers to some questions was even observed. Pre-service teachers have several misconceptions about basic astronomy concepts (Table 9). However, some misconceptions of pre-service teachers about astronomy concepts (Moon rotation, solar eclipse, dimensions, formation of the universe, center of the universe, shape of the Earth) decreased after a four-year undergraduate education, whereas some remained unchanged (day-night cycle, seasons, sun overhead at noon, distances, constellations).

This study revealed that pre-service teachers had some misconceptions on the moves of the Earth and the Sun and the daily equivalents of the phenomenon that occur as a result of these moves. One of these is the misconception about occurrence of the day and night. The education that they receive is thought to be the reason why students cannot fully construct this information in their minds. Therefore, students explain day and night cycle based on their observations. Individuals who do not know the scientific reason for the occurrence of the day and night cycle or who cannot fully construct it in their minds might say "the sun rises and sets every day in the sky, so day and night occur as a result of the Sun's revolution around the Earth". Similarly, Vosniadou (1991) reached the same conclusion in his study and indicated that the students make use of observations in their lives rather than scientific facts when constructing the movement of the Earth. Another misconception is about the time concepts such as "day", "month" and "year". It is thought that students cannot correctly link the time concepts of "day", "month" and "year" which are frequently highlighted in Turkish education system and encountered in our daily lives, with the movements of the Moon, Earth and Sun. Hence, we can conclude that they are mistaken about the duration of the Moon's revolution around the Earth (one month), Earth's rotation (one day) and the Earth's revolution around the Sun (one year). The last misconception on this subject is the pre-service teachers stating that the Moon will be in the phase of "full moon" during the solar eclipse. For this question, reference points and the capacity for three-dimensional thinking and perceiving are very important. Although the position of the Sun and Moon during a solar eclipse was depicted, the students could not imagine the position of the Moon in front of the Sun by looking from the Earth. This can be achieved in planetariums where students have the opportunity to view the sky above other regions and where they can observe and investigate the Earth from a different planet or a star, in other words where they can change the reference system and time (Türk \& Kalkan, 2015).

This study found that the concept that had the lowest rate of correct answers and the most resistant misconception was the concept of seasons. It was found that the pre-service teachers could not implement the knowledge that they had on the subject of seasons to a new situation/problem. The most common two misconceptions of pre-service teachers were found to be "the Earth is closer to the Sun in summer" and "the difference between the seasons would disappear and there would be a single season if the distance between the Earth and the Sun remains the same". Similar misconceptions were observed in studies conducted by Henriques, 2000; Kikas, 1998; Ojola 1992, 1997; Rollins, Denton, \& Janke, 1983; Schnepps 
\& Sadler, 1989. In addition, Trumper (2000, 2001a, 2001b, 2001c, 2003, 2006a) conducted a number of studies on astronomy with primary, secondary and college students. Although students in his studies gave correct answers (seasonal changes result from Earth's axial tilt), they expressed non-scientific opinions to the question of why summers are warmer than winters. Among them, the most common view is that "the Earth is closer to the Sun in summer". Similarly, Henriques (2000) reported that many of the students stated that seasons occur as a result of changes in the distance from Earth to the Sun. The results of many studies have shown that students are of the opinion that the Earth is hotter in summer and colder in winter due to the elliptical orbit rotation of the Earth around the Sun (Kikas, 1998; Ojola, 1992, 1997; Schnepps \& Sadler, 1989). To comprehend the concept of seasons, students should also comprehend the following concepts: axial tilt of the Earth, the relationship between the sunlight intensity per unit area on the Earth, movements of the Earth, lengthening and shortening of days-nights according to seasons, different features of seasons and differing seasons in the Southern and Northern hemispheres at the same time. Otherwise, the students construct the concept of seasons from their daily experiences, beliefs and informal learning. This type of learning is not based on scientific facts and may lead to misconceptions in students' minds. Students probably reach these misconceptions from their everyday experience (if you move an object to a warmer object, its temperature increases and vice versa). This situation can be interpreted as "Since the weather is warm in the summer, The Earth must be close to Sun" by students.

Studies revealed that similar misconceptions are observed in pre-service teaching and elementary school students (Bisard et al., 1994; Lightman \& Sadler, 1993; Trumper, 2001a, $2001 b, 2006 b)$. One of the ways to reduce the misconceptions of elementary school students is to determine the knowledge levels of the students for basic astronomy concepts and to ensure an appropriate educational environment. Therefore, Primary teachers and Science teachers who are supposed to teach astronomy concepts in primary and elementary education should be equipped with adequate knowledge (Kalkan \& Kiroglu, 2007). Because astronomy concepts are abstract, tangible physical scale models, 3D simulation modeling and planetarium environments should be used in teacher education and pre-service teachers should be taught how to use such models in the classroom or other educational environments. Thus, astronomy concepts that are difficult to teach to students in the concrete operational stage with two-dimensional figures can be taught with alternative methods appropriate to a constructivist approach.

While no statistically significant difference was found between the academic achievements of pre-service Science teacher and Primary teacher at the beginning of their university education, it was found that in the fourth year, pre-service Science teachers were more successful than pre-service Primary teachers were. When the results were analyzed in terms of the variable of gender, a significant difference was found only in the first year Science teaching program students in favor of the male students although this difference disappeared in the fourth year. In Turkey, an astronomy course is taught only in the Science teaching program in the faculty of education ( 2 hours a week, single term). Astronomy is not taught as a separate course or included in other courses in Primary teaching. Only in specialized field courses are some 
astronomy concepts taught indirectly. Therefore, Primary teachers will be teaching what they had learned about astronomy in elementary school. Isn't this a vicious circle? Similarly, Bisard et al. (1994) suggested that pre-service teachers and secondary school students have approximately the same level of success and students' knowledge of astronomy does not change dramatically after elementary school. Primary teachers are supposed to teach students basic astronomy concepts during their primary education. This study has presented that pre-service Primary teachers have great number of misconception about the basic concepts of astronomy and that the teaching training that they get does not contribute to the elimination of these misconceptions. Therefore, astronomy courses should be included in the Primary teaching curriculum. Isn't it natural for pre-service teachers to learn the subjects they will teach during university education? In addition, we are of the opinion that increasing the weekly astronomy course hours in the Science teaching program would be beneficial. Thus, pre-service teachers would be provided with the required skills before starting their professional lives. Additionally, it is thought that providing in-service training related to the basic astronomy topics to the teachers in charge, implementing teacher support programs by collaborating with higher education institutions and providing opportunities for the teachers to participate in astronomy courses involved in undergraduate programs would positively influence the quality of astronomy education in Science teaching programs.

\section{Research Limitations and Future Directions}

This study has some limitations. The most important of these limitations is the quantitative nature of the study. The changes in the knowledge of pre-service teachers on some astronomy subjects in their first and fourth year of study were presented numerically. However, it will be of use to make further studies that will present "how" and "why" these changes occur and the changes in these mental models. In addition, studies that use quantitative and qualitative data collection methods together can be planned.

This study found out some misconceptions of pre-service teachers. Pre-service teachers were found to show resistance change in some misconceptions. Qualitative studies are needed to determine how these misconceptions are formed in pre-service teachers, why pre-service teachers show resistance to change in some misconceptions and to determine mental models. In addition, experimental studies that aim to eliminate these misconceptions can be planned.

This study was made with the pre-service teachers of only one university. When it is considered that there are a great number of different socio-economic and cultural regions and universities in Turkey, it is difficult to make generalizations from the results of this study. This study can be implemented on pre-service teachers studying at universities of different socio-cultural structure, the results may be generalized and solutions may be recommended accordingly.

The correct answers to the questions given by pre-service teachers in this study and the results of the studies by Zeilik et al. (1998; 1999), Trumper (2000; 2001c), Kalkan \& Kiroglu (2007) that used similar tests on university students were compared. The numbers of correct answers to some questions are in parallel with studies in literature while some questions have different results than the literature. One of the subjects of future studies will be on 
researching the reason for this situation.

\section{References}

Baxter, J. (1989). Children's understanding of familiar astronomical events. International Journal of Science Education, 11(5), 502-513. http://dx.doi.org /10.1080/0950069890110503

Bisard, W. J., Aron, R. H., Francek, M. A., \& Nelson, B. D. (1994). Assessing selected physical science and earth science misconceptions of middle school through university pre-service teachers: Breaking the science 'misconception cycle'. Journal of College Science Teaching, 24(1), 38-42. Retrieved from http://adsabs.harvard.edu/abs/1994JCSTe..24...38B (accessed 17 May 2014).

Bishop, E. J. (2006). United States astronomy education: Past, present, and future. Science Education, 61(3), 295-305. http://dx.doi.org/10.1002/sce.3730610305

Borghi, L., De Ambrosis, A., \& Massara, C. (1991). Physics education in science training of primary school teachers. European Journal of Teacher Education, 14(1), 57-63. http://dx.doi.org/10.1080/0261976910140107

Burton, F. R. (2001). Do item-discrimination indices really help us to improve our tests? Assessment \& Evaluation in Higher Education, 26(3), 213-220. http://dx.doi.org/10.1080/02602930120052378

Creswell, J. W. (2012). Educational research: Planning, conducting, and evaluating quantitative and qualitative research (4th ed.). Boston, MA: Pearson

Department of Employment, Education and Training. (1989). Discipline review of teacher education in mathematics and science. Canberra: Australian Government Publishing Service.

Fraenkel, J. R., Wallen, N. E., \& Hyun, H. H. (2012). How to design and evaluate research in education. New York, NY: McGraw-Hill.

Fraknoi, A. (1996). Astronomy education: Current developments, future coordination, ed. J.R. Percy, ASP Conference Series 89, Astronomical Society of the Pacific, San Francisco.

Henriques, L. (2000, April 29). Children's misconceptions about weather: a review of the literature, the annual meeting of the national association of research in science teaching, The annual meeting of the National Association of Research in Science Teaching, New Orleans, LA.

Hufnagel, B. (2002). Development of the astronomy diagnostic test. Astronomy Education Review, 1(1), 47. http://dx.doi.org/10.3847/AER2001004

Kalkan, H. \& Kıroğlu, K. (2007). Science and nonscience students' conceptions of basic astronomy concepts in preservice training for education teachers. Astronomy Education Review, 1(6), 15-24. http://dx.doi.org/10.3847/AER2007002

Kikas, E. (1998). The impact of teaching on students' definitions and explanations of astronomical phenomena. Learning and Instruction, 8(5), 439-454. 
http://dx.doi.org/10.1016/S0959-4752(98)00004-8

Klein, C. (1982). Children's concepts of the Earth and Sun: A cross-cultural study. Science Education, 65(1), 95-107. http://dx.doi.org/10.1002/sce.3730660112

Krathwohl, D. R. (2001). A revision of bloom's taxonomy: an overview. In Anderson, L. W., \& Krathwohl, D. R., et al (Eds.) A Taxonomy for learning, teaching, and assessing: A revision of bloom 's taxonomy of educational objectives (pp. 212-218). New York, NY: Longman.

Lightman, A., \& Sadler, P. (1993). Teacher predictions versus actual student gains. The Physics Teacher, 31(1), 162-167.

Mant, J., \& Summers, M. (1993). Some primary-school teachers' understanding of the earth's place in the universe. Research Papers in Education, 8(1), 101-129. http://dx.doi.org/10.1080/0267152930080107

Next Generation Science Standards. (2013). Retrieved from http://nextgenscience.org (accessed 10 September 2014).

Ojala, J. (1992). The third planet. International Journal of Science Education, 14(2), 191-200. http://dx.doi.org/10.1080/0950069920140207

Ojala, J. (1997). Lost in space? The concepts of planetary phenomena held by trainee primary school teachers. International Research in Geographical and Environmental Education, 6(3), 183-203. http://dx.doi.org /10.1080/10382046.1997.9965047

Orpwood, G., \& Souque, J. (1985). Towards the renewal of Canadian science education. II. findings and recommendations. Science Education, 69(5), 625-636. http://dx.doi.org/10.1002/sce.3730690505

Pasachof, J. M., \& Percy J. R. (1990). The teaching of astronomy. Cambridge: Cambridge University Press.

Pasachoff, J. M., \& Percy, J. R. (2005). Teaching and learning astronomy: Effective strategies for educators worldwide. Cambridge, MA: Cambridge University Press.

Percy, J. R. (2006). Teaching astronomy: Why and how? The Journal of the American Association of Variable Star Observers, 35(5), 248-254. Retrieved from http://www.aavso.org/files/webpublications/ejaavso/v35n1/248.pdf (accessed 5 May 2014).

Rollins, M. M., Denton J. J., \& Janke, D. L. (1983). Attainment of selected earth science concepts by Texas high school seniors. Journal of Educational Research, 77(2), 81-88.

Sadler, P. M., (1992). The initial knowledge state of high school astronomy students (Doctoral dissertation) Harvard University, Cambridge, MA.

Schnepps, M. H., \& Sadler, P. M. (1989). A private universe-preconceptions that block learning. Cambridge, MA: Harvard-Smithsonian Center for Astrophysics.

Secretary of State for Education and Science. (1983). Report of the U.S. department of education's national commission on excellence in education. Washington, DC: U.S. 
http://www.ncrel.org/sdrs/areas/issues/content/cntareas/science/sc3risk.htm （accessed 8 January 2014).

Sharp, J. (1996). Children's astronomical beliefs: A preliminary study of year 6 children in south-west England. International Journal of Science Education, 18(6), 631-652. http://dx.doi.org/10.1080/0950069960180601

Sneider, C. I., \& Pulos, S. (1983). Children's cosmographies: Understanding the earth's shape and gravity. Science Education, 67(2), 205-221. http://dx.doi.org/10.1002/sce.3730670209

Tomorrow 98. (1992). Report from the commission on science and technological education. Jerusalem, Israel: Ministry of Education.

Trumper, R. (2000). University students' conceptions of basic astronomy concepts. Teaching Physics, 35(1), 9-15.

Trumper, R. (2001a). A cross-age study of junior high school students' conceptions of basic astronomy concepts. International Journal of Science Education, 23(11), 1111-1123. http://dx.doi.org/10.1080/09500690010025085

Trumper, R. (2001b). A cross-age study of senior high school students' conceptions of basic astronomy concepts. Research in Science and Technological Education, 19(1), 97-109. http://dx.doi.org/10.1080/02635140120046259

Trumper, R. (2001c). A cross-college age study of science and nonscience students' conceptions of basic astronomy concepts in preservice training for high-school teachers. Journal of Science Education and Technology, 10(2), 189-195. http://dx.doi.org/10.1023/A:1009477316035

Trumper, R. (2003). The need for change in elementary school teacher training-a cross-college age study of future teachers' conceptions of basic astronomy concepts. Teaching and Teacher Education, 19(3), 309-323. http://dx.doi.org/10.1016/S0742-051X(03)00017-9

Trumper, R. (2006a). Teaching future teachers basic astronomy concepts-seasonal changes - at a time of reform in science education. Journal of Research in Science Teaching, 43(9), 879-906. http://dx.doi.org/10.1002/tea.20138

Trumper, R. (2006b). Factors affecting students' junior high school students' interest in physics. Journal of Science Education and Technology, 15(1), 47-58. http://dx.doi.org/10.1007/s10956-006-0355-6

Trundle, C. K., Atwood, K. R., \& Christopher, E. J. (2002). .Preservice elementary teachers' conceptions of moon phases before and after instruction. Journal of Research in Science Teaching, 39(7), 633-658. http://dx.doi.org/10.1002/tea.10039

Türk, C., \& Kalkan, H. (2015). The effect of planetariums on teaching specific astronomy concepts. Journal of Science Education and Technology, 24(1), 1-15. http://dx.doi.org/10.1007/s10956-014-9516-6 
Vosniadou, S. (1991). Designing curricula for conceptual restructuring: Lessons from the study of knowledge acquisition in astronomy. Journal of Curriculum Studies, 23, 219-237. http://dx.doi.org/10.1080/0022027910230302

Vosniadou, S. (1992). Knowledge acquisition and conceptual change. Applied Psychology, 41(4), 347-357. http://dx.doi.org/10.1111/j.1464-0597.1992.tb00711.x

Vosniadou, S., \& Brewer, W. (1992). Mental models of the earth: A study of conceptual change in childhood. Cognitive Psychology, 24(4), 535-585. http://dx.doi.org/10.1016/0010-0285(92)90018-W

Vosniadou, S., \& Brewer, W. (1994). Mental models of the day/night cycle. Cognitive Science, 18(1), 123-183. http://dx.doi.org/10.1016/0364-0213(94)90022-1

Yu, K. C. (2005). Digital full-domes: The future of virtual astronomy education. Planetarian Journal of the International Planetarium Society, 34(3), 6-11.

Zeilik, M., Schau, C., \& Mattern, N. (1998). Misconceptions and their change in university level astronomy courses. The Physics Teacher, 36(2), 104-107. http://dx.doi.org/10.1119/1.880056

Zeilik, M., Schau, C., \& Mattern, N. (1999). Conceptual astronomy II. replicating conceptual gains, probing attitude changes across three semesters. American Journal of Physics, 67(10), 923-927. http://dx.doi.org/10.1119/1.19151 


\section{Macrothink Institute ${ }^{\mathrm{m}}$}

Appendix

\section{Appendix 1. Basic Astronomy Test}

1. What causes night and day?

a) The Earth moves around the Sun.

b) The Sun goes around the Earth.

c) The Earth spins on its axis. $\sqrt{ }$

d) Clouds block out the Sun's light.

e) The Earth moves into and out of the Sun's shadow.

2. Beijing, the capital of China, is $90^{\circ}$ to the east of Samsun. Considering the direction in which the Earth rotates, when it is noon in Samsun, what time of day is it in Beijing?

a) Sunrise (morning)

b) Sunset (evening) $\sqrt{ }$

c) Noon

d) Midnight

e) Noon the following day

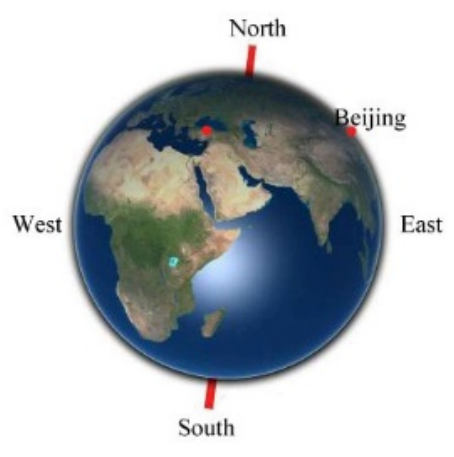

3. How long does it take the Moon to orbit the Earth?

a) An hour

b) A day

c) A week

d) A month $\sqrt{ }$

e) A year

4. In order to observe a total eclipse of the Sun from Earth, in what phase does the Moon need to be?

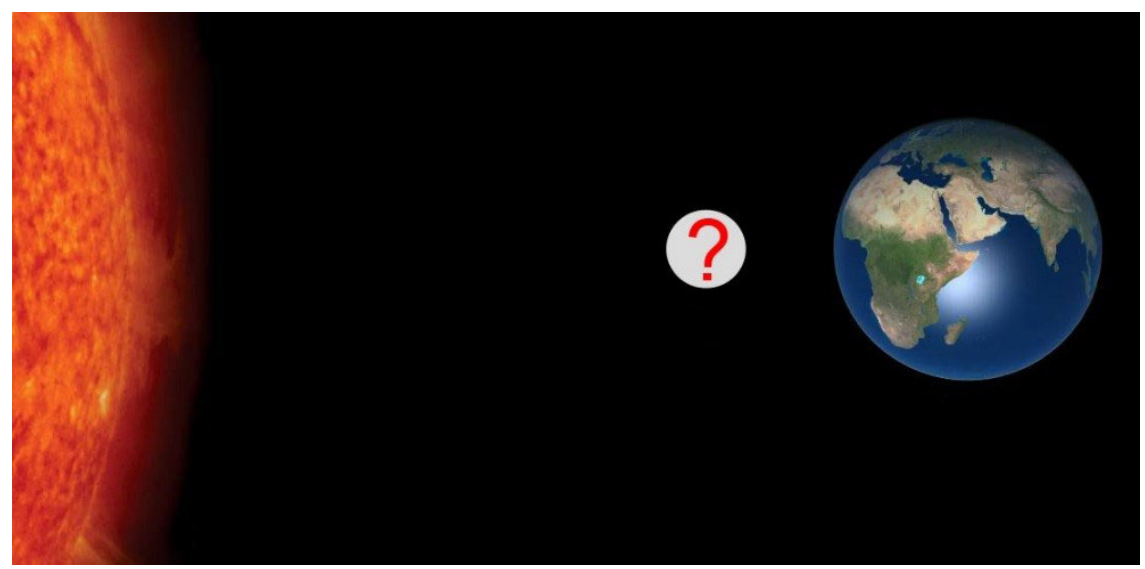
a) Full
b) New $\sqrt{ }$
c) First quarter
d) Last quarter
e) Crescent
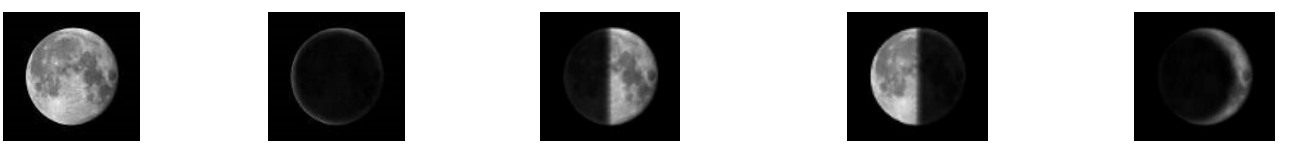


\section{Macrothink}

5. The main reason that it is hotter in the summer than the winter is that

a) The Earth is closer to the Sun in summer.

b) The Earth is farther from the Sun in summer

c) Clouds are less in summer.

d) The Earth's axis points to the same direction relative to the stars, which is tilted relative to the plane of its orbit.

e) The Sun gives off more energy in the summer than in the winter.

6. The Earth follows an elliptical orbit around the Sun, as shown in Fig. I. If the Earth's orbit were changed into a full circle, as shown in Fig. II, the distance between the two bodies would remain the same throughout the year. How would this affect the seasons?

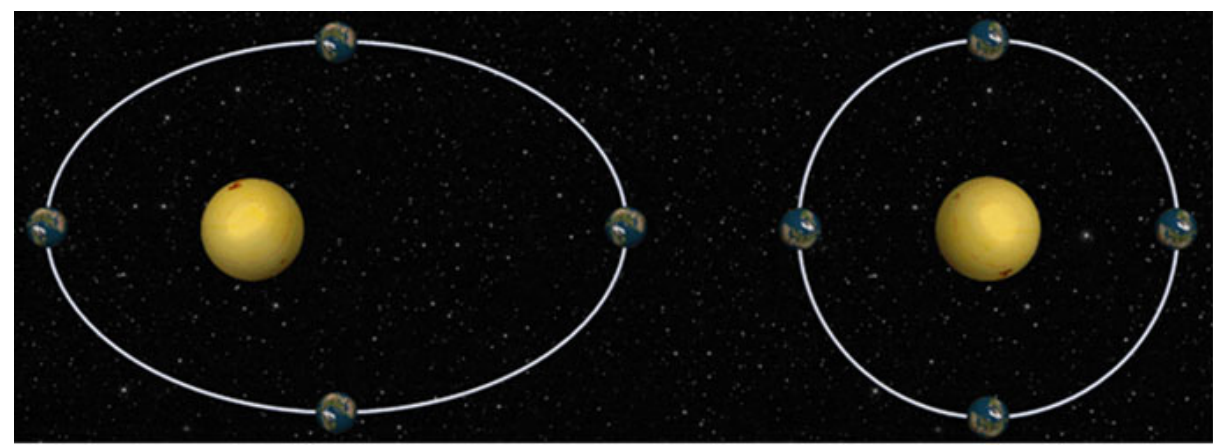

Figure I

Figure II

a) Seasonal temperatures would be different from today

b) There would only be summer and winter

c) There would only be autumn and spring

d) The seasons would be as they are today $\sqrt{ }$

e) The differences between the seasons would disappear and there would be no seasons

7. When the Sun is right above the flag mast, the mast casts no shadow. When can you observe this from your location (Samsun)?

a) Everyday at noon

b) Only on the middle of summer

c) Only on the middle of winter

d) On the first days of autumn and spring

e) Never from where we are (Samsun city) $\sqrt{ }$

8. Which of the following is the correct order of the Sun, the Earth, Jupiter, and the Moon, from the largest to the smallest?

a) Sun, Earth, Moon, Jupiter

b) Earth, Sun, Moon, Jupiter

c) Earth, Moon, Sun, Jupiter

d) Sun, Jupiter, Earth, Moon

e) Sun, Earth, Jupiter, Moon 


\section{Macrothink}

9. Which of the following is the correct order of the celestial bodies, from the nearest to the Earth to the farthest?

a) Andromeda Galaxy, Sun, Jupiter, Polaris

b) Sun, Jupiter, Polaris, Andromeda Galaxy

c) Jupiter, Sun, Polaris, Andromeda Galaxy

d) Sun, Jupiter, Andromeda Galaxy, Polaris

e) Polaris, Jupiter, Sun, Andromeda Galaxy

10. Compared to the distance to the Moon, how far away is the (Turksat B) artificial satellite (when in space) from the Earth?
a) Very close to the Earth
b) About half way to the Moon
c) On the Moon
d) Very close to the Moon
e) About twice as far as the Moon

11. According to modern ideas and observations, which of the following statements is correct?
a) The Earth is the center of the Universe.
b) The Sun is the center of the universe
c) There is no center of the Universe. $V$
d) The Milky Way Galaxy is the center of the Universe.
e) The Pole Star is the center of the Universe

12. Which of the following is the theory explaining the formation of the universe?

a) Evolution theory which explains the change of everything and, therefore, adaptation to the environment

b) Big-Bang theory which presents that universe comes into existence and expands as a result of a big explosion $\sqrt{ }$

c) Mass gravity law which presents that whole substances pull each other

d) Creation theory, which asserts that everything was created out of nothing over time

e) Constant universe theory which presents that whole substances in universe exist since endless

13. Looking up from where you are, the constellation Ursa Major may look like a dipper. The dipper would assume a different shape if you looked up from where?

a) From a city in Southeastern Anatolia

b) From a city in Europe

c) From the Moon's surface

d) From Planet Saturn

e) From a far-away star $\sqrt{ }$ 


\section{Macrothink}

14. Which of the following is the shape of the Earth?
a) Ellipse
b) Sphere
c) Geoid $\sqrt{ }$
d) Round
e) Flat

\section{Copyright Disclaimer}

Copyright reserved by the author(s).

This article is an open-access article distributed under the terms and conditions of the Creative Commons Attribution license (http://creativecommons.org/licenses/by/3.0/). 